\title{
PROTEST AS AN AMERICAN TRADITION: NARRATIVE DISCOURSE IN THE AMERICAN HISTORY SURVEY
}

Kelly Schrems

Bloomington High School

Bloomington, Illinois
Teaching History 46(2)

DOI: $10.33043 / \mathrm{TH} .46 .2 .41-44$

(C) 2021 Schrems.

Distributed with CC BY-NC-ND 4.0 License.

In 1994, on his radio talk show, Rush Limbaugh said, "History is real simple. You know what history is? It's what happened." Limbaugh made this argument amidst debates concerning the role that politicization plays within history curricula, suggesting that history should be taught in matter-of-fact terms. ${ }^{1}$ Yet, in that statement alone, Limbaugh exposed his complete disengagement with history as an academic discipline. Historiography, the process that professional historians engage with, assumes an ever-changing nature to the discipline. In the simplest terms: historians use facts to form arguments. Oftentimes, different historians will use the same facts in forming conflicting arguments. James Loewen, in Lies My Teacher Told Me, states, "History is a furious debate informed by evidence and reason. Textbooks encourage students to believe that history is facts to be learned." ${ }^{2}$ Here, Loewen flaunts the disconnect that exists between history, the academic discipline engrained with controversy, and history, the watered-down, textbook version that puts teenagers to sleep.

An analysis of three surveys of American history, ranging in publication date from 1999-2020, reveals that historians achieve different means in their varying portrayals of the same events. For instance, in his controversial, groundbreaking synthesis of American social history, A People's History of the United States, Howard Zinn suggests that the Spanish-American War was fought to distract American workers from socialist revolt, quoting a socialist newspaper of the time: "...war was 'a favorite method of rulers for keeping the people from redressing domestic wrongs."' 3 Meanwhile, in a more "patriotic," political history of the United States, Land of Hope: An Invitation to the Great American Story, Wilfred McClay suggests that the United States sought to educate, uplift and "help" those left in the wake of Spanish colonial rule. ${ }^{4}$ Different still, Greg Grandin suggests, in The End of the Myth: From the Frontier to the Border Wall in the Mind of America, that fighting the SpanishAmerican War was a means to reunite the Northern and Southern sects of the nation still reeling from the Civil War and Reconstruction: "War with Spain allowed 'our boys' to once more 'be wrapped in the folds of the American flag..."'5 There is little consensus among these historians concerning the ambitions of the SpanishAmerican War, other than the fact that it happened. However, simply stating that "it happened," as Limbaugh suggests, lacks contextualization and makes for a pretty boring history lesson.

Of the survey texts mentioned above, Grandin's An End to the Myth does something quite different through its use of thematic history. Grandin provides a "through-line," a focus alongside chronology with which to organize his narrative. Grandin builds his narrative around the myth of the frontier, the idea that America was exceptional in its ability to expand westward, claiming that the "imagery [of the frontier] could easily be applied to other arenas of expansion, to markets, war, culture, technology, science, the psyche, and politics." 6 Using this through-line, Grandin showcases how Americans have avoided domestic issues by looking to the "frontier," or issues that could be tackled outside their own dominion. The argument is most compelling because Grandin believes that the frontier myth came to an end with Donald Trump's discussion of a border wall. America must

\footnotetext{
${ }^{1}$ Andrew Hartman, A War for the Soul of America: A History of the Culture Wars (Chicago \& London: The University of Chicago Press, 2015), 273.

${ }^{2}$ James Loewen, Lies My Teacher Told Me: Everything Your American History Textbook Got Wrong (New York, London, Toronto, Sydney \& New Delhi: Simon \& Schuster, 2007), 8.

${ }^{3}$ Howard Zinn, A People's History of the United States (New York: HarpersCollins Publishers, 2003), $307-308$.

${ }^{4}$ Wilfred M. McClay, Land of Hope: An Invitation to the Great American Story (New York \& London: Encounter Books, 2020), 236-239.

${ }^{5}$ Greg Grandin, The End of the Myth: From the Frontier to the Border Wall in the Mind of America (New York: Metropolitan Books, 2019), 136-138.

${ }^{6}$ Grandin, An End to the Myth, 3.
} 
now, according to Grandin, face inward to reckon with our domestic issues of race, violence, and exploitation.

Eric Foner, another renowned historian, similarly structures The Story of American Freedom suggesting that the concept of "freedom" can be traced, as a through-line, from the founding of the nation into the late $20^{\text {th }}$ century. Foner's analysis is intriguing as he claims that "freedom" is not a constant for all Americans and does not have a consistent definition. Rather, freedom was molded to fit the context of the time. ${ }^{7}$ Foner's most impressive strength throughout the work is his claim that freedom guaranteed to some means freedom denied to others, resting much of his argument on the understanding that subjugation has been a consistent tool in the maintenance of freedom: "This idea of freedom, it seems, requires an antithesis...." Foner's focus on a constantly changing "freedom," inherent for some and denied to others, lends itself to his inclusiveness of groups oftentimes ignored in the American story, including African Americans, women, immigrants, labor activists, and Native Americans.

Both Grandin and Foner cover the basics. They both discuss the nation's founding. They both recognize the horrors of slavery. They both acknowledge the momentousness of the Civil War and the failures of Reconstruction. They both mention westward expansion, the turn of the $20^{\text {th }}$ century, the World Wars, the Civil Rights Movement, the war in Vietnam, etc. To varying degrees, they touch on most of the major moments, the moments that tend to find themselves organized into pre-packaged units with tests at the end. However, neither Grandin nor Foner gives credence to the idea that their narratives are all-encompassing; in fact, they admit to the opposite. ${ }^{9}$ As overworked, time-constrained teachers find each and every school year, it is impossible to fit every detail one might deem important into the typical American history survey, especially if there is no unifying theme other than chronology. There will always be tough choices concerning what to include. On that front, teachers can learn much from these Pulitzer Prize winning historians about how to weave a coherent, relevant and engaging narrative, free from the fear that they will "leave something out." Rather than picking and choosing what is important based solely on chronology, teachers can identify an engaging concept to inform their narrative, much like freedom for Foner and the frontier for Grandin. A possible and particularly timely concept not explored by these historians is protest.

In the summer of 2020, the nation reeled after the murders of Breonna Taylor and George Floyd with racially-driven protests sparking in major and unassuming cities alike. Black Lives Matter protestors called for responsibility on behalf of the police officers involved and sought reforms of policing tactics across the nation. In many places, protests became violent, including the use of tear gas and rubber bullets by law enforcement and the destruction of property and looting of businesses. Many of the nation's news networks responded by delegitimizing the protests and chastising tactics, rather than focusing on the issues the protestors called attention to. A common sentiment included the idea that Americans of the past did not protest like this, we used to protest the right way. Another sentiment, viewing protest as un-American, also ran rampant. And yet, an understanding of protest throughout American history challenges the idea that past Americans were somehow more moral in their protest tactics or that protesting in this way is new or unseen in America's past.

In 1773, colonists disguised as natives dumped hundreds of chests of tea into Boston Harbor in defiance of taxation imposed by the British empire. In doing so, they destroyed the property of the British East India Company. Defiance against the British empire culminated in the American Revolution, which, itself, can be described as a massive form of protest. After winning their independence, Americans protested, again, during Shays' Rebellion. This time, it was the farmers who had fought in the Revolutionary War and received little compensation into the 1780s. After attempts to draft documents of grievances, the farmers took up arms, violently attacking courthouses. Soon, again, in the 1790s, Pennsylvanians protested against a new tax on whiskey. As before, violence came to define the Whiskey Rebellion.

The protest tradition continued into the $19^{\text {th }}$ century, dominated by race and labor. In August of 1831, Nat

\footnotetext{
${ }^{7}$ Eric Foner, The Story of American Freedom (New York \& London: W.W. Norton \& Company LTD, 1998), xv.

${ }^{8}$ Ibid., 170.

${ }^{9}$ Ibid., xv.
} 
Turner staged one of the largest slave rebellions in United States history, traveling from plantation to plantation, freeing the enslaved while killing enslavers. The rebellion represented one of the most feared possibilities of Southern society: that enslaved people would retaliate against the society that subjugated them through violence. In 1859, John Brown organized a similar abolitionist revolt in Harper's Ferry, Virginia, in an attempt to take over the federal arsenal. On the labor front, the Great Railroad Strike of 1877 saw rail workers organize a strike in opposition to wage cuts. The strike, and subsequent violence, halted the rails and the commerce associated while militiamen mobilized to stop the mayhem. Similarly, begrudged workers revolted violently against the Carnegie Steel Company during The Homestead Strike of 1892.

The beginning of the $20^{\text {th }}$ century continued in a similar fashion with women protesting for the right to vote. Women picketing the White House in the 1910s lambasted President Wilson's refusal to support female suffrage, burning several of Wilson's speeches. These women were met with violent arrest and imprisonment (Alice Paul was famously force-fed raw eggs while attempting a hunger strike at the Occoquan Workhouse). The late $20^{\text {th }}$ century saw even more reliance on protest. The long hot summer of 1967 included race riots. Latinx students walked out of their East L.A. classes in March of 1968 to protest a lack of bilingual support in the public school system. The 1969 Stonewall riot saw members of the LGBTQ+ community defy police harassment, which included barricading officers in the Stonewall Inn and lighting the building on fire. From 1969-1971 the protest group "Indians of All Tribes" occupied Alcatraz Island, claiming the land should be returned to the tribes that had once inhabited it. These historical examples barely scratch the surface of the protest movements employed by generations of Americans and showcase how protest, with its varying tactics, is an American tradition. In this light, the un-American rhetoric that accompanied the 2020 protests is mystifying.

The origin of the American protest tradition can be linked to the conception of the nation, in which not all people gained an equal claim to the founding ideals. The British tradition of liberty had already accepted exclusions. According to Foner, the exclusionary rhetoric of freedom was supplanted to the colonies: “...most eighteenth-century commentators assumed that only certain kinds of persons were fully capable of enjoying the benefits and exercising the rights of freedom. On both sides of the Atlantic...dependents lacked a will of their own and thus were incapable of participating in public affairs." ${ }^{10}$ Foner explains that freedom in early America was tied to several things: the right to vote, economic resources, and political power. ${ }^{11}$ Not only did people not endowed with these advantages not gain "freedom," but the nation bolstered itself on the antithesis of freedom: slavery. Race, gender, and economic status limited who was entitled to partake in American freedom. The nation, then, became even more exclusionary throughout the $19^{\text {th }}$ century by way of westward expansion, laws limiting immigration of certain "undesirable" groups, and the exploitation of wage workers. In each example, those denied equal access to freedom used protest as a tool. Only through protest have women, African Americans, laborers, and many others been able to partake in democracy. From this perspective, protest does not represent a hatred for one's nation but a yearning to be granted liberty and accepted as an American.

The concept of protest is not just an American tradition engrained by the inadequacies of our founding. It also has the type of fiery, controversial appeal that engages teenagers. Students could critically analyze each and every era of American history through the protest movements that occurred during that time, comparing motive and tactic, determining why and how so many Americans across so many generations have tapped into this tradition. Then, rather than ending their intellectual reckoning of the 2020 protests with the farcical rhetoric that Americans used to protest correctly, students could question why these protests occurred, how they relate to past protest movements, and whether or not they will inspire structural change. Students could even question why violence is oftentimes employed as a tactic, by both protestors and those in opposition. This form of critical exploration and inquiry cannot be achieved through the rote-memorization of historical facts. Narrativization, through the use of a through-line, presents history as a tool for critical analysis and does justice to the discipline

\footnotetext{
${ }^{10}$ Ibid., 9.

${ }^{11}$ Ibid., 18-24.
} 
by allowing students to engage with historical questions.

A counterargument to the use of a through-line in the secondary classroom might suggest that the teacher is fabricating a narrative by not following a traditional curriculum. To that suggestion, one can reference Hayden White's The Content of the Form: Narrative Discourse and Historical Representation: "How else can any past, which by definition comprises events, processes, structures and so forth, considered to be no longer perceivable, be represented in either consciousness or discourse except in an 'imaginary' way?"12 Regardless of how we choose to reimagine the past, the past remains inaccessible. It is the discipline of history that attempts to recreate the past in terms that are currently accessible. Although there are facts deemed to be true, there is no correct narrative or way to organize those facts. Regardless of what American schools have presented as a correct narrative, historians constantly rewrite the stories of America's past using varying perspectives. As long as teachers base their narrativization on "what happened," as professional historians do, they can provide a litany of different American stories that relate to their students' experiences and embolden their critical inquiry of modern events.

\footnotetext{
${ }^{12}$ Hayden White, The Content of the Form: Narrative Discourse and Historical Representation (Baltimore \& London: The Johns Hopkins University Press, 1987), 57.
} 